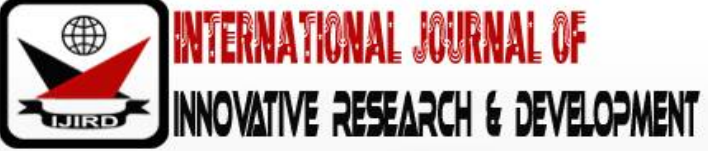

ISSN 2278 - 0211 (Online)

\section{Chemical Properties of Unbranded Vegetable Oils Sourced From Five Different Markets in Benin City, Edo-State, Nigeria}

\begin{tabular}{c}
\hline Isiosio O. Isaac \\
Senior Lecturer, Department of Science Laboratory Technology \\
Delta State Polytechnic, Otefe-Oghara, Delta State, Nigeria \\
Uzezi Edoka Isiosio \\
Lecturer, Department of Biochemistry, Western Delta University, Oghara, \\
Delta State, Nigeria
\end{tabular}

\begin{abstract}
:
Due to higher market prices for branded vegetable oils (BVO), many consumers are compelled to make do with unbranded vegetable oils (UVO) without any details about the manufacturers or where such oils are sourced. This has raised public health concern over suitability of UVO for consumption purposes. This study was carried out to investigates the quality index of UVO sourced from five different markets in Benin City against king's vegetable oil (BVO). Three chemical properties of acid value (AV), iodine value (IV) and saponification (SV) were determined. AV for both BVO and UVO were outside the $0.6 \mathrm{mgKOH} / \mathrm{g}$ stipulated by CODEX STAN 210. No significant difference $(\mathrm{p} \varangle 0.05)$ was observed in the IV for both UVO and BVO. However, UVO sourced from New Benin had the highest IV of $104.48 \pm 7.93\left(\mathrm{I}_{2} / 100 \mathrm{~g}\right.$ ) while the BVO yielded the least IV value of $97.760 \pm 3.6 .69\left(\mathrm{I}_{2} / 100 \mathrm{~g}\right)$. SV was highest in UVO sourced from Oba market $295.3 \pm 29.44(\mathrm{mg} \mathrm{KOH} / \mathrm{g})$ while the BVO with a yield of $129.8 \pm 45.30(\mathrm{mg} \mathrm{KOH} / \mathrm{g}$ ) gave least SV. The three chemical properties of AV, IV and SV for UVO from the different markets where not too far in values when compared with BVO. However, more studies on more chemical parameters and physical properties of UVO in these markets must be carried out to douse fear over consumption of UVO sourced from these markets
\end{abstract}

Keyword: Acid Value (AV), Branded Vegetable Oil (BVO) Iodine Value (IV), Saponification Value (SV), Unbranded Vegetable Oil (UVO)

\section{Introduction}

The main source of dietary lipids are edible vegetable oils (Vaisali, et al., 2014). Edible vegetable oils are food grade oils sourced from oil producing crops such as: corn, oat, cotton, soybean, mustard, camelina, crambe, safflower, sunflower, groundnut, rapeseed, coconut, palm, rape and olives (Sarwar, et. al, 2014, Al Majidi \& Bader, 2015)). The importance of edible oils in human nutrition cannot be overemphasized as they provide distinctive textures, flavour and sensory roles in food products. They are carriers of fat soluble vitamins such as vitamin A, D,E and K (Mengistie and Mekonnen, 2018). Edible vegetable oils are also energy dense. One gram of a lipid sample accounts for 9kilocalories or 37 kilojoules ( against 4 kilocalories for one gram of protein and carbohydrate)(World Health Organization, 2008).

Despite the benefits associated with the utilization of edible oils, concerns have been raised over the potential health risk over lipid intake. High lipid intake has been directly related to an increased risk of obesity, coronary heart disease and some cancers(Martin et al., 2007). More worrisome is the quality of edible oils in circulation in the markets especially in the third world countries. The quality of edible oil is a function of the method of obtaining the oils from their plant sources (Gobena et al., 2018).

In Nigeria, there two types of edible vegetable oils in circulation. These are: branded vegetable oils (BVO) and the unbranded ones (UVO). The branded edible oils are in some cases imported into the country and come with brand names such as: kings, power oil, turkey, sunola, laser, lesieur etc (Okpuzor et al., 2009). Virtually all the branded edible oils are subjected through proper industrial refining processes such as degumming, deacidification, bleaching and deodorization. These processes ensure the removal of undesirable components which can subject the oil to spoilage or rancidity while still retaining the essential portion of the oil (Vaisali, et al., 2014). Unbranded edible oils do not come with the labeled names of the manufacturers and most of them are usually dispensed in used alcoholic bottles or used table water plastic containers. Often, these unbranded edible oils are produced using traditional methods by individuals with no knowledge about modern techniques and underlying principles of oil refining and preservation. Contamination and spoilage are bound to take place. The dynamics of oil spoilage or deterioration is primarily due to oxidation which is a function of the fatty acid content present in the oil(Gobena et al., 2018) Many of our local markets are flooded with UVOs (Atinafu and Bedemo, 2011) often called "groundnut oil" but the sources of raw materials from which UVOs are sourced are difficult to ascertain as there are no labeling ascribed to them. These UVOs enjoy high patronage due to the fact that they are far 
cheaper when compared with the labelled brands. This study was carried out to evaluate the acid value (AV), iodine value (IV) and saponification value (SV) of UVOs purchased from different markets in Benin

\section{Materials and Methods}

In this study, UVO were purchased from five different markets in Benin-city, Edo State, Nigeria. The markets where the oil samples were sourced are: Uselu market, Oba market, New Benin Market, Oliha market and Ramat market. Kings vegetable oil, a branded vegetable oil (BVO) was included in the study as control. In this study, the acronym (UVO) will be used for unbranded vegetable oils while (BVO) will be used for branded vegetable oil.

\subsection{Determination Of Physiochemical Properties}

\subsubsection{Acid Value (AV)}

AV was determined by directly titrating the oil/fat in an alcoholic medium against standard potassium hydroxide/ sodium hydroxide solution (Gashaw and Getachew, 2014).

$1.0 \mathrm{~g}$ of each of the oil samples was dissolved in $50 \mathrm{ml}$ of ethanol in a conical flask. Two drops of phenolphthalein indicator were added. The mixture was boiled for $5 \mathrm{mins}$ and titrated while hot against standard alkali solution, shaking the mixture vigorously during the titration. The last drop is achieved when the colour of indicator changed to pink for at least 30 seconds (Roiaini et al., 2015)

2.1.2. Calculation

Acid value $=\frac{56.1 \times \mathrm{V} \times \mathrm{N}}{\mathrm{W}}$

Where

$\mathrm{V}=$ volume in $\mathrm{ml}$ of standard potassium hydroxide.

$\mathrm{N}=$ Normality of the potassium hydroxide.

$\mathrm{W}=$ weight in $\mathrm{g}$ of the sample.

\subsection{Determination of Saponification Value (SV)}

The saponification value was determined by the method described by Michael and Oscar in food analysis laboratory manual(Nielsen, 2010). $2 \mathrm{~g}$ for each of the oil samples were weighed and introduced into Erlenmeyer flasks. 25 $\mathrm{ml}$ of the alcoholic potassium hydroxide solution was added from a burette into the flasks. A blank determination was conducted along with the sample. Several boiling beads was added to the flasks. The flasks with the samples were connected to condensers and allowed to boil steadily for 30 - 60 minutes on a hot plate until the samples are clear, homogenous and indicating complete saponification. Samples are allowed to cool to room temperature. $1 \mathrm{ml}$ of phenolphthalein was added to samples and then titrated with0.5 N HCl (from a burette) until the pink color just disappears. The volume of used titrant is recorded. The same process is recorded for blank

\subsubsection{Calculation}

Saponification value (SV)

(Vo - V1)x C x 56.1

$\mathrm{m}$

Where 56.1 is equivalent weight of $\mathrm{KOH}, \mathrm{V}_{0}$ is the volume in $\mathrm{ml}$ of standard $\mathrm{HCl}$ solution used for the blank test, $\mathrm{V}_{1}$ is the volume in $\mathrm{ml}$ of the standard $\mathrm{HCl}$ solution used for sample, $\mathrm{C}$ is the exact concentration of the standard $\mathrm{HCl}(0.5 \mathrm{~N})$ solution and $\mathrm{m}$ is the mass in gram of the test portion $(2 \mathrm{~g})$.

\subsection{Determination of Iodine Value (IV)}

Iodine value was determined by method described by Majidi and Bader, (2015 and Gashaw and Getachew (2014). $0.5 \mathrm{~g}$ of oil sample was weigh into $500 \mathrm{ml}$ conical flask with glass stopper. This was followed with addition of $25 \mathrm{ml}$ of carbon tetrachloride. $25 \mathrm{ml}$ of wijs solution was pipetted into the flask such that the amount of iodine was $50-60 \%$ in excess of that absorbed by the fat. The flask was allowed to stand for 30 minutes in the dark with occasional shaking. After incubation in the dark, $20 \mathrm{ml}$ of potassium iodide solution was added to the flask. The flash was shaken thoroughly before addition of $100 \mathrm{ml}$ of freshly boiled and cooled water to remove any free iodine on the stopper. Liberated iodine was titrated with standardized sodium thiosulphate solution, using starch as indicator until the blue colour formed disappears after thorough shaking with the stopper on. Blank was also conducted in the same manner.

\subsubsection{Calculation}

Iodine value (IV) $=$

$\frac{12.69(\mathrm{~B}-\mathrm{S}) \mathrm{N}}{\mathrm{W}}$

Where,

$\mathrm{B}=$ Volume in $\mathrm{ml}$ of standard thiosulphate solution required for the blank.

$\mathrm{S}=$ Volume in $\mathrm{ml}$ of standard thiosulphate solution required for the sample.

$\mathrm{N}=$ Normality of the standard thiosulphate solution

$\mathrm{W}=$ weight in $\mathrm{g}$ of the sample. 


\section{Statistical Analysis}

The results were expressed as mean $\pm S . D$ ( $n=$ no of sample). One-way analysis of variance (ANOVA) was used to test for difference among all the groups. Significant difference between groups were detected in ANOVA using turkey's post hoe test and a value of $\mathrm{p}(<) 0.05$ was considered as statically significant. All statistical analyses were performed using the graph pad instat 3 software (Graphpad software Inc. San Diego, USA)

\section{Results}

\begin{tabular}{|c|c|c|c|}
\hline Samples & $\mathbf{A V ( \mathbf { m g ~ K O H } / \mathbf { g } )}$ & $\left.\mathbf{I V} \mathbf{( I}_{\mathbf{2}} / \mathbf{~ 1 0 0 g}\right)$ & $\mathbf{S V} \mathbf{( m g ~ K O H} / \mathbf{~ g})$ \\
\hline Control & $1.22 \pm 0.00^{\mathrm{a}}$ & $97.760 \pm 3.6 .69$ & $129.8 \pm 45.30^{\mathrm{a}}$ \\
\hline Uselu & $3.93 \pm 0.55^{\mathrm{d}}$ & $99.30 \pm 11.43$ & $248.3 \pm 0.00^{\mathrm{c}}$ \\
\hline Oliha & $3.55 \pm 0.33^{\mathrm{d}}$ & $98.99 \pm 7.73$ & $182.5 \pm 6.93^{\mathrm{b}}$ \\
\hline Oba & $1.87 \pm 0.33^{\mathrm{b}}$ & $88.66 \pm 5.87$ & $295.3 \pm 29.44^{\mathrm{d}}$ \\
\hline New Benin & $2.24 \pm 0.00^{\mathrm{c}}$ & $104.48 \pm 7.93$ & $182.5 \pm 6.93^{\mathrm{b}}$ \\
\hline Ramat & $3.56 \pm 0.02^{\mathrm{d}}$ & $98.560 \pm 6.98$ & $261.5 \pm 14.20^{\mathrm{d}}$ \\
\hline
\end{tabular}

Table 1: Results for Acid Value (AV), Iodine Value (IV) and Saponification Value (SV) Results Were Expressed as Mean \pm S.D of Triplicate Determination. Values In Same Column with Different Superscript Differ Significantly $(\mathrm{P} \varangle 0.05)$

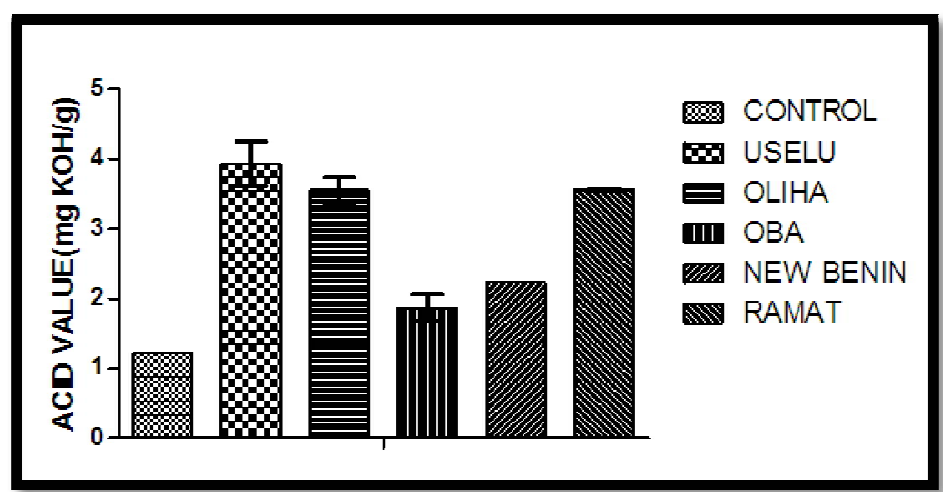

Figure 1: AV of UVO Samples and BVO Sample

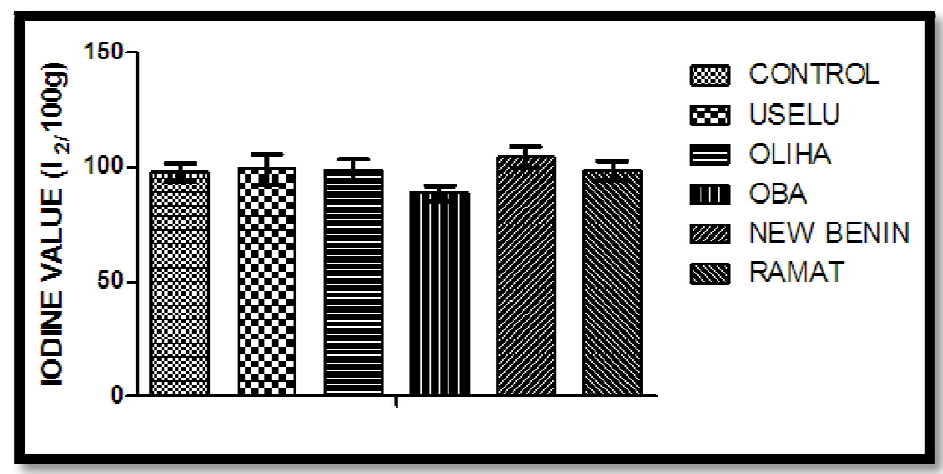

Figure 2: IV of UVO Samples and BVO

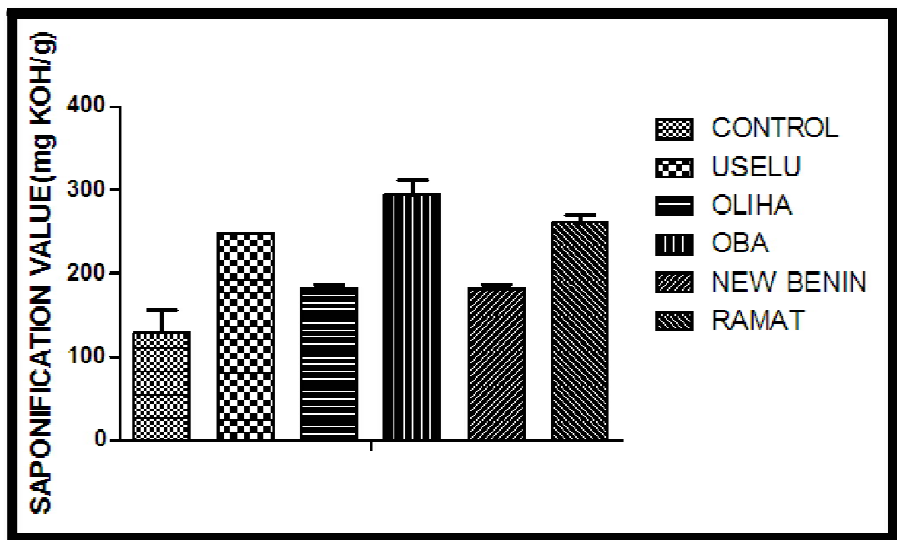

Figure 3: SV of UVO Samples and BVO 
UVOsourced from Uselu market had the highest acid value $(3.93 \pm 0.55 \mathrm{mg} \mathrm{KOH} / \mathrm{g})$. There was no significant difference between UVO acid values obtained from Uselu market, Oliha $(3.55 \pm 0.33 \mathrm{mg} \mathrm{KOH} / \mathrm{g})$ and Ramat $(3.56 \pm 0.02 \mathrm{mg}$ $\mathrm{KOH} / \mathrm{g}$ ) markets. Lower acid values were obtained UVO for New Benin $(2.24 \pm 0.00 \mathrm{mg} \mathrm{KOH} / \mathrm{g})$ and Oba market (1.87 \pm 0.33 $\mathrm{mg} \mathrm{KOH} / \mathrm{g})$. The control, BVO however, gave the least acid value $(1.22 \pm 0.00 \mathrm{mg} \mathrm{KOH} / \mathrm{g})$ which has significant value when compared with all the UVO.

The highest iodine value was recorded in UVO obtained from New Benin $\left(104.48 \pm 7.93 \mathrm{I}_{2} / 100 \mathrm{~g}\right)$. This value was followed by $99.30 \pm 11.43 \mathrm{I}_{2} / 100 \mathrm{~g}$ for Uselu market, $98.99 \pm 7.73 \mathrm{I}_{2} / 100 \mathrm{~g}$ for Oliha market, $98.56 \pm 6.98 \mathrm{I}_{2} / 100 \mathrm{~g}$ for Ramat Market and $88.66 \pm 5.87 \mathrm{I}_{2} / 100 \mathrm{~g}$ for Oba market. The least iodine value was recorded in the BVO with value of $97.760 \pm 3.6 .69 \mathrm{I}_{2} / 100 \mathrm{~g}$. There is no significant difference in the iodine values obtained for both UVO and the control BVO. The highest saponification value was observed for UVO sourced from Oba market $(295.3 \pm 29.44 \mathrm{mg} \mathrm{KOH} / \mathrm{g})$. This value was followed by saponification value for UVO from Ramat market $(261.5 \pm 14.20 \mathrm{mgKOH} / \mathrm{g})$, Uselu market $(248.3 \pm 0.00$ $\mathrm{mgKOH} / \mathrm{g})$, New Benin market (182.5 $\pm 6.93 \mathrm{mgKOH} / \mathrm{g})$ and Oliha market (182.5 $\pm 6.93 \mathrm{mgKOH} / \mathrm{g})$. The least saponification value was obtained in the BVO $(129.8 \pm 45.30 \mathrm{mgKOH} / \mathrm{g})$.

\section{Discussion}

Acid value, expressed as the amount of $\mathrm{KOH}$ in milligram required to neutralize free fatty acid in $1 \mathrm{~g}$ of oil. It is an important factor in the evaluation of the quality of edible oil ((Almajidi and Bader, 2015), because it expresses the amount of fatty acids which have been liberated by hydrolysis from the glycerides due to the action of moisture, temperature and/ or lypolytic enzyme lipase(FSSAI, 2015). The Codex Standard for Named Vegetable Oils ( CODEXSTAN210-1999) stipulated $0.60 \mathrm{mg} \mathrm{KOH} / \mathrm{g}$ acid value for refined oils (CODEX STAN 210, 2001). The presence of excess free fatty acid and other fatty materials in oils bring about the offensive odour and taste in the oil on long storage (Ayoade, et al.2015). All samples subjected to AV analysis presented values higher than $0.6 \mathrm{mg} / \mathrm{KOH}$ as stipulated by CODEXSTAN210-1999. However, the BVO presented the lowest AV $(1.22 \pm 0.00 \mathrm{mg} \mathrm{KOH} / \mathrm{g})$ which also has a significant different $(p<0.05)$ when compared with AV obtained for all UVOs. Elevated AV may be adduced to long storage period after processing and this can lead to rancidity (Okpuzor et al., 2009). This may also be due to lack of proper technology to remove free fatty acids during refining process.

Iodine value is a measure of the amount of unsaturation of fats and oil (FSSAI, 2015) and hence their potential to become oxidized(IAFMM, 1981).It is expressed in term of the number of grams of iodine absorbed by 100 grams of edible oil. Unsaturated fatty acids absorb iodine at their double bonds. As the degree of unsaturation increases, iodine number and hence biological value of the edible oil increases(Yadav, 2018). Also, the oil becomes more vulnerable to oxidation and production of free radicals (Madhavi and Saroja, 2014). Results from this study indicate that most of oil samples are rich in unsaturated as seen from high iodine values for most of the samples analyzed. The UVO sourced from New Benin market gave the highest iodine value of $104.48 \pm 7.93 \mathrm{I}_{2} / 100 \mathrm{~g}$. Results for iodine values in this study are in conformity with the results obtained byAlmajidi and Bader, (2015),(Ogunka-Nnoka, Igwe, Orubite, \& Gomez Garcia, 2015)(Wali, et al.,2015)and (Chabiri et al., (2009).

Saponification value is defined as the weight of potassium hydroxide, in milligrams, needed to saponify one gram of oil (Sadoudi and Ahmed, 2017). SV measures the average chain length of the fatty acid that makes up the oil. It is a useful tool in providing information about the type of glycerides and mean weight of the acids in a given oil sample. The lower the SV, the larger the molecular weight of fatty acids in the glycerides and vice versa (Mengistie et al., 2018). The results of SV for the test samples showed a significant difference with the control. However, SV value for Oliha and New Benin markets posted the same values $(182.5 \pm 6.93 \mathrm{mg} \mathrm{KOH} / \mathrm{g})$. This value is within the range of SV obtained for crude palm superolein (180-205 mg KOH/g oil) on the(CODEX STAN 210).

Observed differences in SV can be as a result of the raw materials from which the UVO is extracted. Due to the fact that all the UVO is not labelled, the raw materials from which they are sourced is often not known. UVO sourced from Ramat, Oba and Uselu market are predominantly made up of shorter chain fatty as can be deduced from high SV.

\section{Conclusion}

Despite concerns over the quality assurance of UVO sold in our markets, results from this study buttress the fact that they are not too far in quality when compared with the BVO. However, more studies need to be carried out to evaluate physical properties and more chemical properties of UVO oils in circulation in major markets in Benin city to further authentic their safety for consumption purpose.

\section{Reference}

i. Almajidi, M., and Bader, A. (2016). Physicochemical characteristics of some imported edible vegetable oils in Iraq. Research Journal of Pharmaceutical, Biological and Chemical Sciences (RJPBCS), (January 2015), 448-494.

ii. Atinafu, D. G., \& Bedemo, B. (2011). Estimation of total free fatty acid and cholesterol content in some commercial edible oils in Ethiopia, Bahir DAR. Journal of Cereals and Oil Seeds, 2(6), 7176. https:/ / doi.org/ 10.5897/ JCO11.025

iii. Ayoade, G.W, A. I. . and V. O. E. A. (2015). Physicochemical and Fatty Acid Composition of Crude and Refined Oils of African Canarium. 4(5), 230-234.

iv. Chabiri, S. A., M., Hati, S. S., Dimari, G. A., Ogugbuaja, V.O. (2009). Comparative Quality Assessment of Branded and Unbranded Edible Vegetable Oils in Nigeria .10(2), 927-934.

v. CODEX STAN 210 (2001). Codex standard for named vegetable oils. Codex Alimentarius, 8, 11-25.

vi. FSSAI. (2015). Manual of methods of analysis of foods: Oils and Fats. New Delhi. 
vii. Gashaw, A., \& Getachew, T. (2014). Cholesterol Content and Free Fatty Acids in Edible Oils and Health Effects: A review. 2321-9653. Retrieved from www.ijraset.com

viii. Gobena, W., Girma, S., Legesse, T., Abera, F., Gonfa, A., Muzeyin, R., ... Yohannes, T. (2018). Microbial safety and quality of edible oil examined at Ethiopian public health institute, Addis Ababa , Ethiopia : a retrospective study. 6(3). https:/ / doi.org/ 10.15406/jmen.2018.06.00203

ix. IAFMM. (1981). iodine determination in fish.pdf (pp. 1-4). pp. 1-4. London: IAFMM.

x. Madhavi, N., \& Saroja, T. D. (2014). International Journal of Pharma and Bio Sciences ISSN chemical constants of some edible oils within the state of Andhra Pradesh. 5(3), 437-440.

xi. Martin P., D. D. and, \& Charles, P. (2007). oil for food: The global story of edible lipids. Journal of World-Systems Research, XIII(1), 12-32.

xii. Mengistie, T., Alemu, A., \& Mekonnen, A. (2018). Comparison of physicochemical properties of edible vegetable oils commercially available in Bahir Dar, Ethiopia. 4(2), 130-135.

xiii. Nielsen, S. S. (2010). Food Analysis Laboratory Manual (second). New York: Springer.

xiv. Ogunka-Nnoka, C. U., Igwe, F. U., Orubite, K. O., and Gomez Garcia, R. (2015). Comparative Study of the Physicochemical Properties and Fatty Acid Composition of Some Indigenous Spices in Nigeria. International Journal of Biochemistry Research \& Review, 5(2). https:/ / doi.org/ 10.9734/ IJBcRR/ 2015/ 13305

xv. Okpuzor, J., Okochi, V. I., Ogbunugafor, H. A., Ogbonnia, S., Fagbayi, T., \& Obidiegwu, C. (2009a). Estimation of cholesterol level in different brands of vegetable oils. Pakistan Journal of Nutrition, 8(1), 57-62. https:/ / doi.org/ 10.3923/ pjn.2009.57.62

xvi. Roiaini, M., Ardiannie, T. and Norhayati, H. (2015). Physicochemical properties of canola oil, olive oil and palm olein blends. International Food Research Journal, 22 (3), 1227-1233.

xvii. Sadoudi, R. and Ali Ahmed, D. (2017). Studies on physico-chemical characteristics and fatty acid composition of commercially available Algerian frying edible oils. 24(February), 60-67.

xviii. Sarwar, M.F., Sarwar. M.H., Muhammad Sarwar, M., Qadri, N.A and Moghal, S. (2014). The role of oilseeds nutrition in human health: A critical review. Journal of Cereals and Oilseeds, 4(8), 97-100. https:/ / doi.org/ 10.5897/ jco12.024

xix. Vaisali, C., Charanyaa, S., Belur, P. D., \& Regupathi, I. (2015). Refining of edible oils: A critical appraisal of current and potential technologies. International Journal of Food Science and Technology, 50(1), 13-23. https:/ / doi.org/ 10.1111/ijfs.12657

xx. Wali, F., Baloch, M. K., Nawaz, M., \& Khan, K. (2015). Comparison of Some Physico-Chemical Properties of Different Oils Available in the Local Market in Pakistan. 2(2), 93-98.

xxi. World Health Organization. (2008). Fats and fatty acids in human nutrition. Report of an expert consultation. In FAO food and nutrition paper (Vol. 91). https:/ / doi.org/ I1953E/ 1/ 11.10

xxii. Yadav, S. (2018). Edible oil adulterations : Current issues, detection techniques, and health hazards Edible oil adulterations: Current issues, detection techniques, and health hazards. (January). 